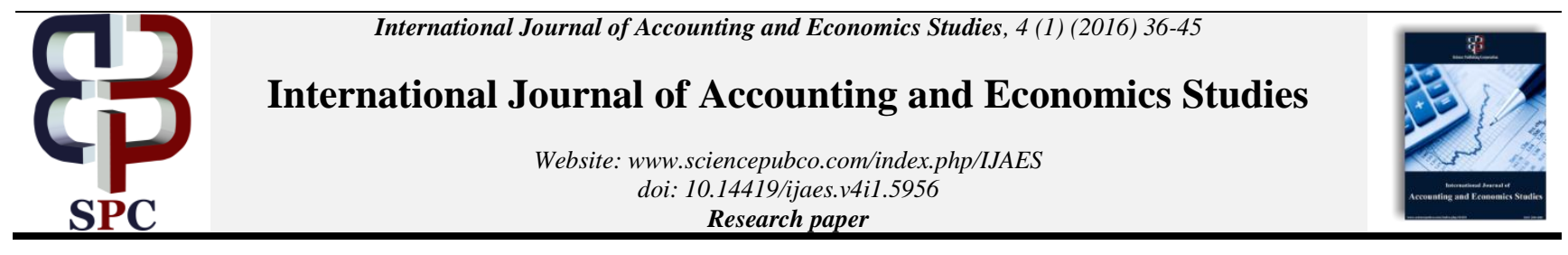

\title{
Effect of fair value accounting on the company's reputation
}

\author{
Olfa Riahi $^{1 *}$, Walid Khoufi ${ }^{2}$ \\ ${ }^{1}$ PhD student at the Faculty of Economics and Management of Sfax-Tunisia \\ ${ }^{2}$ Professor at the Institute of Business Studies of Sfax-Tunisia \\ *Corresponding author E-mail: olfa-riahi@hotmail.com
}

\begin{abstract}
The purpose of this paper is to study in the French context the impact of the application of fair value on the shareholder value creation by comparing the information's relevance of accounting indicators of French corporate groups in the industrial sector included in the CAC All-Tradable between pre-fair value period (2001-2003) and the post-fair value (2005-2007). Using the method of logistic regression permits us to demonstrate, firstly, that the variables of traditional character still retain their rank as key indicators determining stock return whatever the accounting principle relating thereto, and we noticed, on the other hand, that there is a marked improvement in information content of variables if and only they were submitted as understandable and uncomplicated under the model of fair value.
\end{abstract}

Keywords: Fair Value; Historical Cost; Value Relevance; Value Creation.

\section{Introduction}

After trying to align by itself the national accounting frameworks as part of the implementation of the seventh Directive of 1983 on consolidated accounts, the European Union refrained resorting to the adoption of all available IAS standards except 32 and 39. Indeed, by the July 2002 regulation, the European Union decided that all European listed companies should adopt for their consolidated accounts from 2005 a new accounting framework called IAS / IFRS produced by a private law body, the IASB, based in London. This regulation has been the adequate refuge for European companies which finance increasingly on foreign markets and have long suffered from the high cost of adjustments to their accounting statements to make them comparable and understandable to readers. It has become essential to improve the comparability of financial statements. In addition, many incidents that have highlighted the global economic sphere and have had an impact on the direction of international business have strengthened control and excited a new wave of change in accounting rules to put the trust accounting information quality. To achieve the goals mentioned above, the adoption of an universal and intelligible accounting language would be useful. This language was operated by the establishment of international accounting standards based on economic and financial fundaments and which neglect the legal or patrimonial aspect.

This vast movement aimed, in fact, to replace the historical cost basis of accounting fundamental valuation of assets and liabilities, and to replace it by the concept of fair value. The IASC defines fair value as "the amount for which an asset could be exchanged or a liability assumed between two willing parties informed in a transaction with conflicting interests". In Europe, the delicate notion of fair value has not been immune to several debates. This is approvable by the multitude and frequency of regulations governing its implementation. Moreover, several annoyances have arisen about the impact of this principle on the financial state- ments and its issues in terms of financial stability. This accounting model based on the Anglo-Saxon model that emphasizes the preeminence of an economic approach to the detriment of fiscal historical approach will appear absolutely rigorous transmutation in financial communication. The latter represents a tool monitoring decision and evaluation taken by leaders to assess the created value and the future development aspects of the firm including its image. Examining the creation of shareholder value leads necessarily to explain the influence on the value of the firm a phenomenon likely to upset the company's trajectory (Parienté, 1997), that the accounting of fair value can be a case. In this context, the creation of value would constitute a measure of the relative credibility of financial policy (Jacquet, 1997) and is located at the terminal of the strategy and finance which lead to put themselves in a strategic perspective valuation (Desmoutier, 1994; Koch and Trémolière 1995). Thus, the interest of this research is on the one hand, to popup the causal link between the concept of value creation and the image of the company, and to analyze the impact generated by the fair value on the perception of the creation of shareholder value, on the other. This concept of value creation brings, therefore, an importance by shareholders and investors to accounting information for the purpose of evaluation. It would be necessary to analyze the correspondence between the information content of accounting data and the various transactions in the financial markets. This encourages us, in fact, to question the usefulness and relevance of accounting data due to the principle of fair value accounting. In this perspective, this paper will attempt to answer the central question: Does the introduction of accounting fair value model allows to improve the informational extended accounting data for investors? The answer to this question is closely related, in fact, to the definition of the following objectives:

- Study in the French context, the impact of applying the fair value on the creation of shareholder value of listed companies in order to verify whether it will provide a good image of the company; 
- Compare value relevance of information content between some accounting indicators published under the principle of historical cost and under the principle of fair value.

This paper is organized as follows: We will present in the first section the theoretical literature relating to current research of value relevant, the hypothesis of this research will be the second section. The last two sections are devoted to the presentation of the methodological aspects and the main results of our empirical analysis.

\section{Literature review}

The development of the fair value emanates more questions about the relevance of the additional value of this accounting method. Until the 1970s, the Accounting Research Studies approaching these issues in purely theoretical terms; it called the normative approach which has proposed logical arguments to justify the importance of accounting in relation to another. But, by the development of financial theory, an empirical approach takes the place of that of normative. Indeed, the relevance of accounting information is derived through the quality of the relationship between the accounting data and the enterprise value (Landsman and Maydew, 1999) and to justify the informational value of accounting information, empirical studies are based on two fundamental contributions namely the efficient market hypothesis and the Capital Asset Pricing Model (CAPM). The results of most studies conducted have shown that the relevance of accounting information reported in the annual financial statements has been declining over the years. Harris and al. (1994) for example, found a weak association between stock market valuation and accounting variables in the German market. This can be explained by the decline of the relevance of traditional accounting data for evaluation to investors. Affes, Baklouti and Jammoussi (2006). From 1990, the fair value has held a boom in the United States and around the world in order to propose remedies for the failure of the existing accounting method that is the historical cost. In fact, the crisis of American savings banks in the eighties and the expansion of financial in struments have raised the issue of the relevance of accounting information based on the principle of historical cost. Thus, the relevance of accounting information is a subject that has been well documented since the publication of Ball and Brown and Beaver studies (1968). The accounting literature is very rich when it comes to study and test the relevance of fair value accounting in the different models in the world. These empirical studies have analyzed the relevance of accounting information based on the hypothesis that this information has an additional explanatory power compared to historical cost. They focus mostly on samples representatives of US banks. Taken together, the results of empirical studies have attempted to discern the relevance of fair value in terms of its outcome in stock returns are on one hand positive, and mixed and do not show a pre- significant excellence of the method of fair value compared to valuation at historical cost, on the other hand.

\subsection{Research studies with positive results}

Barth (1994) studied the relevance of information on investment securities held by US banks which are measured at fair value for the period 1971 to 1990 . The author concluded that fair value accounting has a power additional explanatory value in the stock price by comparing it with the evaluation at historical cost. Ahmed and Takeda (1995) showed that the fair value of unrealized gains and losses related to investment securities have a direct impact on stock returns. Their study was based on a sample of US commercial banks from the second quarter of 1986 to the fourth quarter of 1991. Moreover, Barth, Beaver and Landsman (1996) also found an informational superiority of fair value model in relation to the valuation model at historical cost. The study concerned 136 largest US banks over the period 1992-1993. The results show that the fair value of loans, securities and long-term debt that is issued by lapses of SFAS 107, able to better explain the current bank shares as historical cost. The same result was found by Eccher, Ramesh and Thiagarajan (1996) who indicated that information on the fair value of loans, long-term debt and investment securities have informational content more than the historical cost. Their study examined 624 US banks over the period 1992-1993. As part still in the same line of investigation, Venkatachalem (1996) revealed the presence of a significant relationship between the fair value of derivatives and the value of company shares applying the requirements of SFAS 119. The study of Schrand (1997) also confirmed this result. These two studies have shown, in fact, a direct link between the fair value of derivatives and changes in stock returns. Park and al. (1999) found in a study on the analysis of gains and unrealized losses related to securities available for sale that they are statistically associated with the stock performance. Carroll, Linsmeir and Petroni (2003) concluded that there is a strong correlation between the share price and the fair values of the majority of shares and also between latent results and stock market returns. These authors took the sample of 143 investment companies with fixed capital presenting balance sheets and income statements which are published almost entirely at fair value. Bartov and al. (2005) have made the comparison between the relevance of the results published in several accounting standards including IFRS. The authors found that the results alerted under USGAAP and IFRS, which adopt the principle of fair value accounting, are more relevant than those published in the German local standards. Barth and al. (2008) also found in a study of 21 countries that the adoption of IFRS including the principle of fair value can improve the quality of accounting information by showing that the net income and equity are more relevant under IFRS than under local standards. Igor Gorchakov (2009) found that the use of fair value can be relevant and it can influence the decisions of investors provided it is measured in a reliable way. Saadi (2010) compared the relevance of net income and shareholders' equity which are published in French local standards and IFRS in the period 2000-2007. The results showed a significant improvement in information content of accounting data published in the financial reporting after adopting IFRS and their principle which is fair value.

\subsection{Research studies with mixed results}

Nelson (1996) showed that only actions that are measured at fair value are relevant to explain market capitalization. However, loans, long-term deposits and debts recorded under the principle of fair value have no information content. His study was based on a sample of 279 banks for the period 1992-1993. Moreover, Barth and Clinch (1998) confirmed that the fair value of intangible assets is relevant; however, that of tangible assets has no information content for all firms. The sample was composed of 350 Australian companies over the period from 1991 to 1995. JuettnerNauroth (2003) indicated that the fair value of derivative instruments is irrelevant when it comes to instruments traded in an active market. The study was concerned with the analysis of the relationship between the market value of the share and the fair value of derivatives determined according to IAS 39 in an inactive market. The same result was found by Khurana and Kim (2003) which showed that the relevance of fair value information is detected only for securities traded on liquid markets and for large firms and most followed by financial analysts. The authors used a sample of 302 US banks over the 1995-1998 period. These results "sometimes contradictory" Chtourou (2006) were not able to unanimously reveal that fair value information has additional explanatory power compared to historical cost. The poor results of this work can be explained by the non-generalization of fair value accounting for all balance sheet items in some companies such as banks and insurance companies (Elabidi and Hamdi, 2009) and by the lack of the inevitable methodological consistency. 


\section{Hypotheses development}

Referring to the IFRS conceptual framework, it turns out well that relevant information would require the optimal allocation of resources, valuing the firm at its fair value and the fair distribution of the wealth created among the different stakeholders of the company (Colasse 2000). Hence, the results of this research are concerned and tend to show that information based on IFRS is more relevant for the stock market than those derived from a framework based on historical cost. As we have already mentioned, previous research studies (Ball and Brown, 1968; Beaver, 1968; Collins and Kothari, 1989, Easton and Harris, 1991; Strong, 1994; Dechow, 1994, Lev and Zarowin, 1999, Ball and Brown, 1968, Beaver, 1968; Dumontier and Labelle, 1998) have extensively studied the information content and relevance of accounting data. The majority of these studies (Byrne, 1996; Biddle and al., 1997; Dodd and Chen, 1997) were developed in the United States to study the intensity of the relationship between stock returns and several performance assessment indicators enclosing traditional indicators and new indicators of value creation for shareholders. It is due to the great importance accorded by the shareholders and investors to the accounting information for purpose of evaluation that this desire to study the links between the information content of accounting data and financial market emerges. Thus, the accounting data will be designated as relevant in the company's assessment regarding whether the created value resulting from these internal data is correlated to the value of stock market data evaluated on the financial market. However, the principle of fair value resulting from a GAAP (IAS / IFRS) that the development of standards of financial disclosure quality is among its objectives, has to admit in principle that accounting data will "win" in terms of relevance and "reflect as closely as possible" the performance achieved by the company over a given period (Saadi, 2010). Indeed, the International Financial Reporting Standards introduced in the European Union in 2005 has undoubtedly had a huge impact on the financial reporting of firms and converted the meaning and significance of several accounting indicators for investors.

It is in this sense; Barth and al. (2008) pre-estimate that the quality of accounting data can be improved by adopting a qualified and more stringent accounting standards as IFRS that adopt the famous principle which is the fair value. Thus the first hypothesis to be tested is:

H1: Accounting indicators assessed under the principle of fair value are carriers of information for investors about the value created by the firm during an exercise more than those affected by the historical cost.

To see the impact of the transition to the principle of fair value on the quality of financial reporting, we take a financial approach. To this end, we choose a set of variables that prove largely affected by fair value, which from the literature are the most important for financial disclosure and which investors and financial analysts give them importance. These variables are the earnings per share (EPS), equity (EQ), financial assets and goodwill. Indeed, investors are still putting their focus on outcome measures and to address the difficulties of interpretation of these measures, EPS is always their refuge (Martinez, 2004). Thus, Beaver (1998) recommended that EPS takes the most attention from investors and financial analysts and it is significantly associated with stock returns (Ramond Batsch and Casta (2007). The equity was also considered among the performance measures that contain information which can serve as a signal to investors and therefore well explain stock return (Dodd and Chen, 1997). The Study of Barth and al. (2008) which is mentioned in the synthesis of the literature confirmed that the equity and net income are more relevant under the principle of fair value. Similarly, financial assets still show a significance link with the market performance. Moreover, until the nineties, research studies in the US prove the existence of a significant association between financial assets and the market value of the company (Hassan, Percy and Jenny Stewart, 2006). For goodwill, research studies have shown the existence of a positive and significant correlation between the accounting data and the stock price and therefore the stock return (Mather and Peasnell 1991; Seethamraju 2003, and Cazavan 2003). Therefore, by referring to the above, we will argue that the informational content of accounting data (EPS, EQ, financial assets and goodwill) would be more appropriate under the principle of fair value than the historical cost. Thus, the following sub-hypotheses are made:

H1.1: The principle of fair value is more relevant than historical cost to disclose earnings per share (EPS) which carries information to investors on the stock return.

H1.2: The principle of fair value is more relevant than historical cost for disclosing equity (EQ) that carry information to investors on the stock return.

H1.3: The principle of fair value is more relevant than historical cost to disclose financial assets (FINAS) that carry information to investors on the stock return.

H1.4: The principle of fair value is more relevant than historical cost for disclosure of goodwill $(\mathrm{GW})$ which carries information to investors on the stock return.

Theoretically, previous research studies show an overall increase in the information content of financial statements issued under the requirements of IFRS. With the adoption of IFRS and the application of fair value, should be a profound change in the existing financial reporting system by local standards. Hence companies will therefore have the financial statements more relevant with accounting and financial data that better reflect the economic reality of the entity (Wagenhofes and Ewert, 2005).Thus, the principle of fair value is more relevant than historical cost in the disclosure of accounting data that carry information to investors on the stock return. Similarly, in the other hand, like the majority of recent studies have shown, IFRS recognizes business leaders a wide margin of maneuver in the preparation of financial statements (Jeanjean and Stolowy, 2008; Christensen and al. 2009). Therefore, the way to the fair value recommended by this framework will be based on estimates and forecasts derived from management; this will incur a higher volatility in the information provided by the firm, which is not without effects for investors. In this case, the principle of fair value will attack the information content and therefore the relevance of the data assigned to it. The outputs of the financial statements will reflect a subsequent evaluation of the profitability that is established in an approach based on the present and the future approach to the detriment of legal and historical approach. Barth and al. (2001) insisted that the publication of accounting data under highest quality standards better reflect the economic reality of the company. So a strong explanatory power is expected in a model dealing with variables subject to the principle of fair value than historical cost. Khurana and Kim (2003) tested the explanatory power of a model based on historical cost and one based on fair value; they found that the model dealing with variables submitted in the fair value is more explanatory than the one based on historical cost. In this respect, the second hypothesis is as follows:

$\mathrm{H} 2$ : The accounting data submitted to the principle of fair value should improve the explanatory power of the model compared to those submitted to the historical cost.

In practice, empirical work aimed to validate the superiority of the principle of fair value on the historical cost in terms of relevance have often contrasted and mixed results.

\section{Methodology}

This research follows a hypothetical-deductive approach based on an association study. This is based on the analysis of the relationship between the value created by the firm in the financial market and accounting indicators. Indeed, association studies often aim to demonstrate how the stock market performance is consistent with the accounting measures.

In fact, these latter provide information on past performance and market measures rather reflect the expectations of financial analysts on future revenues. 


\subsection{The research sample}

We decided to focus our work on French companies. The population of our sample consists of French industrial companies groups studied over a period of seven years (2001-2007). These companies are included in the CAC All-Tradable indices listed in the first and second market of the Paris Bourse. The choice of the industry for our study seems interesting because of the large mass of the companies belonging to it and which are in number of 71 Indeed, the constitution of our sample took place in several stages. First, we eliminated companies that do not close their financial year on 31 December. Then we deviate companies whose data is not available for the period of our study. After eradication of senseless data, the sample includes a total of 22 companies. The accounting and stock market data for selected companies are collected from their financial statements in annual reports and reference materials that have been extracted either from their official websites and the website of the Paris Stock Exchange or the site of the French financial markets authority. The stock information is daily while the accounting data are annual. Thus, to analyze the informational usefulness (relevance) accounting data on the basis of historical cost and according to the fair value, our sample will be divided into two subsets observed on a pre-fair value period (2001-2003) and post-fair value (2005-2007). The 2004 financial year was ousted in the sample for two arguments. First, it is commonly acknowledged that IFRS 1 has given several optional and mandatory exemptions to groups that apply for the first time IFRS retrospectively to facilitate the transition to the new standards. In fact, the majority of companies have chosen particularly to prepare their consolidated financial statements for 2004, without application of IAS 32 and 39 for financial instruments that enact the application of fair value. Then the decision to exclude 2004 can be justified also by the possibility of finding opportunistic manipulation of accounting results in that year. Indeed, managers may be more likely to manipulate their results during this transition year to escape from all floating fatal results and to keep them within a certain range during the mandatory application of the fair value. The final sample thus determined includes a total of 22 companies.

\subsection{Measurement of variables}

Our work will be raised by dividing the analysis into two parts; namely the measurement of the dependent variable and the extent of the explanatory variables.

\subsubsection{Measurement of the dependent variable}

All decisions from any investor will simultaneously affect the value created by a company. So, assuming the efficiency of financial markets, stock prices will represent suitable repository of the value of a firm and stock market returns will therefore be a relevant measure of the created value (Saadi, 2010).

These returns are calculated as follows:

$R_{i t}=\left(P_{z}+D I V_{i}-P_{i t-1}\right) / P_{i, t-1}$

Where:

$R_{i t}$ The stock return of $\mathrm{i}$ in period $\mathrm{t}$

$P_{i t}$ The price of share i at the end of the year $\mathrm{t}$

$D I V_{\text {it }}$ Dividends paid by firm $\mathrm{i}$ in year $\mathrm{t}$

$P_{i t,-1}$ The price of share $\mathrm{i}$ at the end of the year $\mathrm{t}-1$

\subsubsection{Measurement of explanatory variables}

It should be recalled that the explanatory variables are the earnings per share (EPS), equity (EQ), financial assets (FINAS) and goodwill (GW).

The choice of these variables was analyzed in part of research hypotheses and the measures will be presented below.

\subsubsection{Earnings per share (EPS)}

Earnings per share are the fraction of results attributable to each ordinary share. It corresponds to the adjusted income of the company divided by the number of existents shares and those to create in the future. Thus, it is the result divided by number of shares.

\subsubsection{Equity (EQ)}

There is no specific IAS for equity. According to preliminary explanations of the conceptual framework, they represent the residual interest in the assets of the company after deducting all of its liabilities. They include various categories of capital, capital additions, reserves and equivalents, deferred results and the positive or negative results.

\subsubsection{Financial assets (FINAS)}

Financial assets correspond to all the company's investments, loans that it has made to other companies or even other receivables related to equity investments. Indeed, they are among the balance sheet items that receive the most attention from investors and have been affected by several changes in their accounting following the application of IFRS and their famous principle of fair value.

\subsubsection{Goodwill (GW)}

The goodwill approach is one of several methods that are concerned about the financial assessment of companies. It is also called a purchase gap that evokes according the requirements of IFRS 3 the excess of acquisition cost at a stake or merger of the share of the acquirer in the fair value of identifiable assets and liabilities.

\subsection{The empirical model}

To discern the impact of the application of the principle of fair value on the image of the company in terms of value creation, we used to measure the appropriateness of accounting data in the market valuation of a firm. To do this, we study the association between stock returns and the variables according to the historical cost on the one hand and on the principle of fair value, on the other hand. In other words, we will determine from models based on stock return, if the value created by the firm and observed on the market is appropriate to that published through the accounting indicators. Thus the model based on stock return will be as follows:

$\mathrm{R}_{\mathrm{it}}=\alpha_{0}+\alpha_{1}\left(\mathrm{VC}_{\mathrm{it}} / \mathrm{P}_{\mathrm{i}, \mathrm{t}-1}\right)+\alpha_{2}\left(\mathrm{VC}^{2} \mathrm{it}_{\mathrm{t}} / \mathrm{P}_{\mathrm{i}, \mathrm{t}-1}\right)+\cdots+\alpha_{\mathrm{k}}\left(\mathrm{VC}^{\mathrm{k}} \mathrm{k}_{\mathrm{t}} / \mathrm{P}_{\mathrm{i}, \mathrm{t}-1}\right)+\varepsilon_{\mathrm{it}}$

Where:

$\mathrm{P}_{\mathrm{it}}$ : The price of share $\mathrm{i}$ at the end of the year $\mathrm{t}$

$\mathrm{VC}_{\mathrm{kit}} / \mathrm{Pi}, \mathrm{t}-1$ : correspond to the selected explanatory variables accounting for the firm (i) at time t, divided by the share price at the beginning of the period.

$\mathrm{k}$ : number of variables

Thus, the main focus of our empirical work is to identify the relevance of selected variables namely; earnings per share (EPS), equity (EQ), financial assets and goodwill in the interpretation of stock returns before and after the application of the principle of fair value in the financial statements of groups of French industrial companies selected. In this regard, two empirical regressions are performed. The first regression seeks to study on the pre-fair value (2001-2003) at historical cost, the information content of the issued variables that are published in accordance with the requirements of the French General Accounting Plan. In the second regression, we test on the post-fair value (2005-2007), the information content of the issued variables which are published under IFRS. Models (M1 and M2) have the stock returns based on earn- 
ings per share, equity per share, financial assets per share and goodwill per share.

However, analysis of the informational relevance of each of these four variables requires consideration of four additional models which are: M1.1, M1.2, M1.3 and M1.4 (pre-fair value) and M2 .1, M2.2, M2.3 and M2.4 (post-fair value)

- The M1.1 and M2.1 models have stock return based on earnings per share (EPS)

- The M1.2 and M2.2 models regress the stock returns based on equity per share (EQ)

- $\quad$ The M1.3 and M2.3 models interpret the stock returns based on financial assets per share (FINAS)

- The M1.4 and M2.4 models have the stock returns based on the goodwill per share $(\mathrm{GW})$

Regression according to the historical cost principle

M1:

$$
\begin{gathered}
\mathrm{R}_{\mathrm{it}}=\beta_{0}+\beta_{1}\left(\mathrm{EPS}^{\mathrm{HC}} \mathrm{it} / \mathrm{P}_{\mathrm{it}-1}\right)+\beta_{2}\left(\mathrm{EQ}^{\mathrm{HC}}{ }_{\mathrm{it}} / \mathrm{P}_{\mathrm{it}-1}\right)+\beta_{3}\left(\mathrm{FINAS}^{\mathrm{HC}}{ }_{\mathrm{it}} / \mathrm{P}_{\mathrm{it}-1}\right) \\
+\beta 4\left(\mathrm{GW}^{\mathrm{HC}}{ }_{\mathrm{it}-1} / \mathrm{P}_{\mathrm{it}-1}\right)+\varepsilon_{\mathrm{it}}
\end{gathered}
$$

M1.1: $\mathrm{R}_{\mathrm{it}}=\beta_{0}+\beta_{1}\left(\mathrm{EPS}^{\mathrm{HC}}{ }_{\mathrm{it}} / \mathrm{P}_{\mathrm{it}-1}\right)+\varepsilon_{\mathrm{it}}$

M1.2: $\mathrm{R}_{\mathrm{it}}=\beta_{0}+\beta_{1}\left(\mathrm{EQ}^{\mathrm{HC}}{ }_{\mathrm{it}} / \mathrm{P}_{\mathrm{it}-1}\right)+\varepsilon_{\mathrm{it}}$

M1.3: $\mathrm{R}_{\mathrm{it}}=\beta_{0}+\beta_{1}\left(\mathrm{FINAS}^{\mathrm{HC}} \mathrm{it} / \mathrm{P}_{\mathrm{it}-1}\right)+\varepsilon_{\mathrm{it}}$

M1.4: $\mathrm{R}_{\mathrm{it}}=\beta_{0}+\beta_{1}\left(\mathrm{GW}^{\mathrm{HC}} \mathrm{it}_{-1} / \mathrm{P}_{\mathrm{it}-1}\right)+\varepsilon_{\mathrm{it}}$

Regression according to the principle of fair value

M2:

$$
\begin{aligned}
& \mathrm{R}_{\mathrm{it}}=\beta_{0}+\beta_{1}\left(\mathrm{EPS}^{\mathrm{FV}} \text { it } / \mathrm{P}_{\mathrm{it}-1}\right)+\beta_{2}\left(\mathrm{EQ}^{\mathrm{FV}} \text { it } / \mathrm{P}_{\mathrm{it}-1}\right)+\beta_{3}\left(\mathrm{FINAS}^{\mathrm{FV}} / \mathrm{P}_{\mathrm{it}-1}\right) \\
& +\beta 4\left(\mathrm{GW}^{\left.\mathrm{FV}_{\text {it }-1} / \mathrm{P}_{\mathrm{it}-1}\right)+\varepsilon_{\mathrm{it}}}\right.
\end{aligned}
$$

M2.1: $\mathrm{R}_{\mathrm{it}}=\beta_{0}+\beta_{1}\left(\mathrm{EPS}^{\mathrm{FV}}{ }_{\mathrm{it}} / \mathrm{P}_{\mathrm{it}-1}\right)+\varepsilon_{\mathrm{it}}$

M2.2: $\mathrm{R}_{\mathrm{it}}=\beta_{0}+\beta_{1}\left(\mathrm{EQ}^{\mathrm{FV}} \mathrm{it} / \mathrm{P}_{\mathrm{it}-1}\right)+\varepsilon_{\mathrm{it}}$

M2.3: $\mathrm{R}_{\mathrm{it}}=\beta_{0}+\beta_{1}\left(\mathrm{FINAS}^{\mathrm{FV}} / \mathrm{P}_{\mathrm{it}-1}\right)+\varepsilon_{\mathrm{it}}$

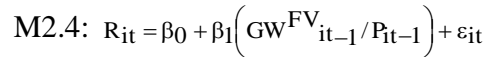

Where:

$\beta_{0}$ : Constant

$\mathrm{R}_{\mathrm{it}}$ : The stock returns of the firm $\mathrm{i}$ at time $\mathrm{t}$

HC: Historical cost

FV: Fair value

EPS $^{\mathrm{HC}}$ it: earnings per share of firm $\mathrm{i}$ at time $\mathrm{t}$ based on historical cost
EPS $^{\mathrm{FV}}{ }_{\mathrm{it}}$ : earnings per share of firm $\mathrm{i}$ at time $\mathrm{t}$ based on the fair value

$\mathrm{EQ}^{\mathrm{HC}}{ }_{\mathrm{it}}$ : equity of firm $\mathrm{i}$ at time $\mathrm{t}$ based on historical cost

$\mathrm{EQ}^{\mathrm{FV}}{ }_{\text {it }}$ : equity of firm $\mathrm{i}$ at time $\mathrm{t}$ based on the fair value

FINAS $^{\mathrm{HC}}{ }_{\text {it }}$ : Total financial assets of firm $\mathrm{i}$ at time $\mathrm{t}$ based on historical cost

FINAS ${ }^{\mathrm{FV}}{ }_{\mathrm{it}}$ : Total financial assets of firm $\mathrm{i}$ at time $\mathrm{tt}$ at fair value $\mathrm{GW}^{\mathrm{HC}}{ }_{i \mathrm{t}}$ : goodwill of firm $\mathrm{i}$ at time $\mathrm{t}$ based on historical cost $\mathrm{GW}^{\mathrm{FV}}{ }_{\mathrm{it}}$ : goodwill of firm $\mathrm{i}$ at time $\mathrm{t}$ based on the fair

$\mathrm{P}_{\mathrm{i}, \mathrm{t}-1}$ : the share price of firm $\mathrm{i}$ at the end of year $\mathrm{t}-1$

$\varepsilon_{\mathrm{it}}:$ random error

\section{Empirical results}

\subsection{Descriptive analysis}

After discriminating the French corporate groups selected in two sub-samples (pre- and post-fair value fair value), it is necessary to describe the explanatory variables and the dependent variable within each sub-sample and in the total sample. The following table presents the descriptive statistics of the stock returns (Ri), earnings per share (EPS), equity (EQ), financial assets (FINAS) and goodwill $(\mathrm{GW})$ knowing that these variables are expressed in Euro and per share for the period 2001-2007.

Analysis of descriptive statistics shows that after the mandatory application of the principle of fair value, the average of stock returns have improved markedly. Indeed, companies in the pre-fair value sample showed an average of stock return $(-0.03456)$ which is lower than this of the post fair value sample $(0.2933)$. This result reflects the positive impact of the principle of fair value on creating shareholder value. In contrast, we find that the average of earnings per share has deteriorated after application and the introduction of the principle of fair value in the financial statements of French companies: 0.1918 prior to the application of the principle of fair value and 0.0884 after the application of the principle of fair value. It can be derived that the accounting data submitted under the principle of fair value were well above and away the flexibility to shape the accounting profit used by managers. Hence, the decline of these manipulations that are attached to the historic cost assessment models in the creation of results will provide a secure assessment of the financial structure of the most companies by affecting the volume of outcome and therefore the level of equity. Indeed, these last showed also an average that has deteriorated through a model promoting the principle of fair value. They spent an average of 1.3332 to 0.5312 .

A comparison of other variables of two sub-samples shows that average of financial assets and goodwill after the application of the principle of fair value are always lower. This deterioration is explained well by the vast impact of the new provisions from the new IFRS. Indeed, until 2003 at least, the French corporate groups were still good students of accounting requirements of French General Accounting Plan. Financial assets were not yet not subject to the new IFRS principles enacted in IAS 39 for example and other standards attached thereto. Hence, it is reasonable to observe that the average of financial assets rose from 0.1924 to 0.0540 . The values of the goodwill resulting from the application of fair value have also deteriorated with an average of $42.67 \%(0.3102$ against 0.5410). This shows the impact of IAS 36 which excludes amortization used by the French General Accounting Plan in favor of an annual impairment test based on fair market value. 
Table 1: Descriptive Statistics of Selected Accounting and Financial Variables in the Two Sub-Samples

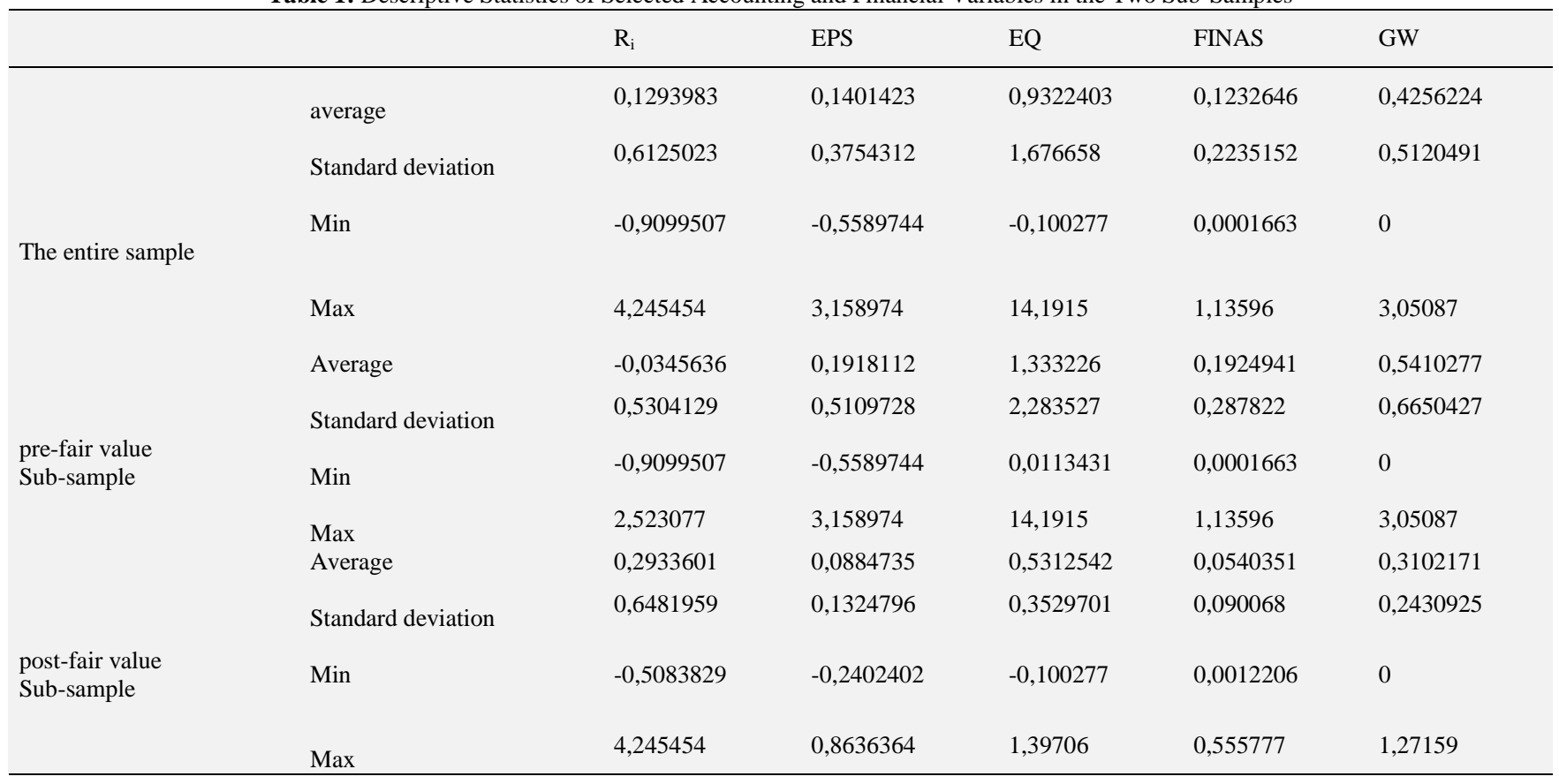

On the other hand, the comparison of variances of the sub-samples (see diagram below), showed that the application of the fair value induces more variability in stock returns that is not the case of explanatory variables which are less variable. This reveals that when these variables are based on the fair value (historical cost) principles are subject to adjustments and were composed by frequentatives elements (dispersed).

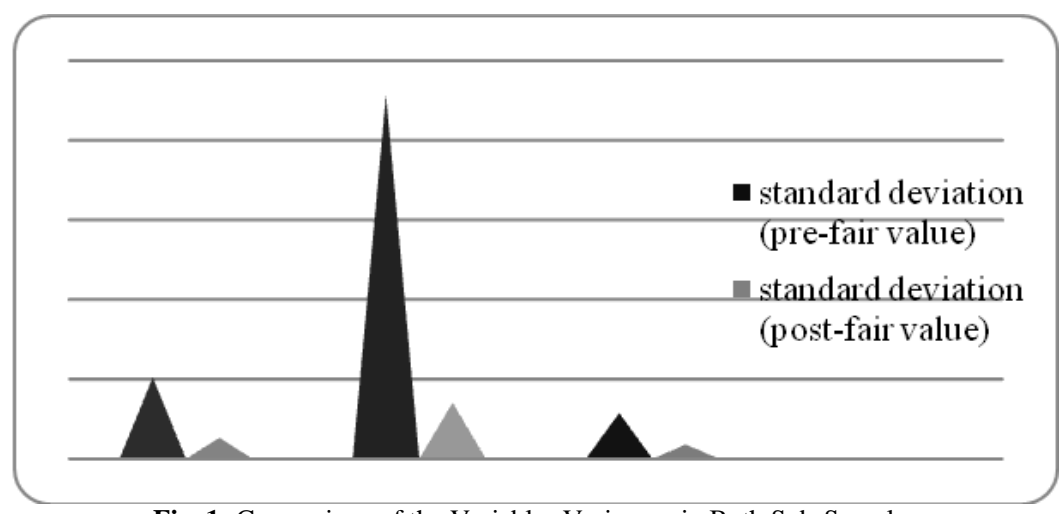

Fig. 1: Comparison of the Variables Variances in Both Sub-Samples

\subsection{The regression analysis}

Before addressing the two regression analyzes (bivariate and multivariate), and to determine which estimator would give better results on our data, it is necessary to go through certain steps. These latter will be described below.

\subsubsection{The multicollinearity of the explanatory variables}

To confirm the existence of links between the independent variables, it is ordinary to use the Pearson correlation coefficient. This coefficient measures the existing linear relationship between two variables. Its value ranges from -1 (the variables are negatively correlated) and +1 (variables are positively correlated). In our study, a correlation is considered important if the Pearson coefficient exceeds a threshold value which is 0.8 . The appendix.1 shows that the correlations are statistically significant and that there is no multicollinearity problem between the explanatory variables for both the models (M1) and (M2) (all Pearson coefficients do not exceed the value 0.8 ).

\subsubsection{Specification tests of the individual effects}

The homogeneity of the constant test is able to decide whether to accept or reject the hypothesis of equality of Bi responds perfectly to this finding. If we assume that the errors are consistent and follow a normal distribution, that is to say that we are faced with the acceptance of the null hypothesis of equality of the constants Bi suggesting that there is only a common hunt, then we can estimate these models by the ordinary least squares (OLS). Thus, the estimator (OLS) is considered the best when the acceptance of the null hypothesis of equal probability constant $\mathrm{Bi}$ exceeds $5 \%$ and then we talk about a common effect. However, if we believe in the existence of individual effects specific to each sample countries. Therefore, we introduce in our model a company-specific intercepts; we will be in front of a rejection of the null hypothesis of equality of the constants Bi. The estimation will be made, therefore, using a panel data after verification that the probability of accepting the null hypothesis of equality of constants $\mathrm{Bi}$ is less $5 \%$ and therefore we talk about a specific effect. Stata 10 , with which we have made all our regressions, directly gives the Fisher statistical regression with fixed effects. In our case, the p-value (Prob> F) associated with the Fisher test is less than 0.005 for all our models. It seems then that there are indeed specific effects specific to each 
company of the sample and the estimation of all our models is done using panel data.

\subsubsection{The hausman test}

In the presence of models with individual specific effects, the question that immediately arises is to identify the type of these individual effects. In addition, the temporal dimension of our sample was found little if we compared to what is often found in micro panels, hence, there may be very large dissimilarities between the GLS estimator (generalized least square) used in the case of the random effects model and the within estimator that is used in the fixed-effects models (Hausman, 1978). We then resorted to Hausman specification test (1978) which is able to determine if the coefficients of the two estimates (fixed and random) are statistically different and decide which estimation's method is adopted. This test thus serves to discriminate the fixed (Within estimate) and random (GLS estimation) effects. Indeed, the estimation is made by GLS estimator if the probability of accepting the null hypothesis, which states that the GLS estimator is better than the Within estimator, is greater than 5\%. Moreover, the estimation of models will be made by the Within estimator when the probability of accepting the null hypothesis, which also stipulates that the GLS estimator is better than the Within estimator, is less than $5 \%$. The results obtained with the Hausman test (1978) on our models support the Within estimation for models M1 , M1.2, M1.4, M2, M2.2 and M2.4 and the GLS estimator for models M1.1 , M1.3 , M2.1 and M2.3 .

\subsubsection{The test for heteroscedasticity}

We talk about heteroscedasticity when the variances of the variables located in the model are different. It corresponds, in fact, in case when the variance of the error variable is not constant. Heteroscedasticity does not bias the coefficient estimations, but the usual induction is no longer valid since the deviations found are not the right ones. Several tests exist to detect it (Goldfeld and Quant test, White test, Lagrange Multiplier test, test Breush Pagan test, etc.). The heteroscedasticity test performed in our research study (see Apendix 4) is operated using the Breush Pagan test. The null hypothesis of this test requires the absence of heteroscedasticity (or presence of homoscedasticity; that is to say that all the coefficients of the regression of squared residuals are zero). The result of this test is a Fisher statistic with k-1 degrees of freedom This test is performed with Stata 10 that shows a probability wich greater than the 5\% threshold in models M1, M1.2, M1.4, M2, M2.2 and M2.4. We can therefore accept the null hypothesis, which implies that these models are homoscedastic. Furthermore, the other models in the study (M1.1, M1.3, M2.1 and M2.3) have lower probabilities at the $5 \%$ threshold, wich make them a heteroscedastic models, hence, it is important to obtain more information on the form of the heteroscedasticity. Indeed, the second dimension of the panel data is to ensure that the variance is the same for all individuals for all $\mathrm{t}$. To do this, a modified Wald test will be used to test the null hypothesis of inter-individual homoscedasticity. The obtained results show the presence of inter-individual heteroscedasticity for M1.1 and M1.3 models and intra-individual Homoscedasticity associated with inter-individual heteroscedasticity for models M2.1 and M2.3). This confirms the estimation of these models by the GLS method that considers the presence of heteroscedasticity.

\subsubsection{Autocorrelation errors test}

We opt to use the Wooldridge test (2002) programmed in Stata to verify the absence of autocorrelation in errors. This test checks if the errors are autocorrelated in autoregressive form (AR1). The null hypothesis states the absence of autocorrelation errors, accepting this hypothesis suggests that errors are not autocorrelated of order.1. The results found lead to accept the null hypothesis, which suggests concluding the absence of autocorrelation in its general form in all models of the study.

\subsubsection{The results derived from the models estimation}

Under different models presented, the additional informational relevance of the principle of fair value will be appreciated by comparing the determination coefficients of regression (R2) displayed on two periods before the application of fair value (20012003) and after the application of fair value (2005-2007). However, the statistical credibility of these comparisons is ensured by the extent of structural change test or the Chow test (1960). The estimation results of the latter wich is performed by using Eviews 5 are summarized in the table below.

\begin{tabular}{lll}
\multicolumn{3}{c}{ Table 2: Results Chow Test } \\
\hline Stat. of Fisher-Snedecor & Probability & null hypothesis \\
\hline 3,140605 & 0,019490 & Rejected \\
\hline
\end{tabular}

The hypothesis are:

H0: stable model

H1: unstable model

- Model coefficients are stable if the probability is greater than $5 \%$

- Model coefficients are unstable if the probability is less than $5 \%$

According to the results, we reject the null hypothesis of the Chow test, which announces that the regression parameters are statistically different between the pre- and post- fair value fair value with a probability of over $95 \%$. Therefore, this result confirms a change in practices after the application of fair value. Thus, we have the right to make the comparison of $\mathrm{R} 2$ between the period of historical cost and the period of the fair value.

Hereinafter, we are interested in the first part, to present the bivariate analysis of metric associations (simple linear regressions M1.1, M1.2 M1.3, M1.4, M2.1, M2.2, M2.3 and M2.4). The second part is devoted to the multivariate analysis of the impact of the fair value on the image of the company in terms of value creation (Multiple linear regressions M1 and M2).

\subsubsection{The bivariate analysis}

The correlation between earnings per share (EPS), equity (EQ), financial assets (FINAS), goodwill $(\mathrm{GW})$ and stock returns is measured by the determination coefficient of regression (R2). This latter will tell us on the informational content of the accounting indicators and it expressed their ability to reflect the information conveyed on the market and incorporated into the stock return of the firm. The regression coefficients (B1) draw correlations that are formulated between the accounting variables and stock returns. In other words, they measure the sensitivity of the relative change in stock returns resulting from a change in accounting indicators. The results of estimating models M1.1, M1.2 M1.3, M1.4 and M2.1, M2.2, M2.3, M2.4 where we empirically tested the relevance of the information content of earnings per share (EPS), equity (EQ), financial investments (FINAS) and goodwill (GW) separated in the French context before and after the application of the principle of fair value show that all the regression coefficients are positive and significant at the $1 \%$ level except the model regressing goodwill on the whole sample where $\beta 1$ is positive and significant at $5 \%$ and the model regressing financial assets on the entire sample that is with a not significant $B 1$. Thus, it seems that earnings per share, equity, financial assets and goodwill are relevant indicators in evaluating companies. The results also indicate a positive and significant Fisher value at 5\% except models regressing financial assets and goodwill on the entire sample that are not significant. This result says that the earnings per share and equity still represent two key determinants variables of stock return. (Brown and Beaver, 1968; Collins and Kothari, 1989; Easton and Harris, 1991; Strong, 1993; Dechow, 1994; Dodd and Chen, 1997; Lev and Zarowin, 1999; Dumontier and Labelle, 1998, Martinez, 1999; Janin 2002; Saadi, 2010). In addition, by comparing the coefficients of determination R2 for each variable, we conclude that the earnings per share recorded in the principle of fair value (M2.1) $(77.41 \%)$ has more informational content than that calcu- 
lated under the historical cost (M1.1) (61.1\%). Our result confirms the claims of Carroll, Linsmeir and Petroni (2003), Bartov and al. (2005), Barth and al. (2008) and Saadi (2010) which stipulate a clear improvement of the information content of net income after the application of fair value. Hence, it seems that the fair value has improved the relevance of earnings per share. So the H1.1 hypothesis is confirmed. Regarding equity, the results were against our predictions. Indeed, the coefficient of determination of the model (M2.2) (18.59\%) is lower than that of the model (M1.2) (51.43\%), thus resulting a deterioration of the relevance of equity coming from the use of principle of fair value. This finding contradicts the scope of Barth and al. (2008). So equities based on the principle of historical cost are more relevant than those affected by the principle of fair value for disclosure of information on creating shareholder value. The founded results invalidate, therefore, the hypothesis H1.2. In addition, contrary to hypothesis H1.3, financial assets seem also to be more relevant in the pre - fair value period to disclose information on the creation of shareholder value than the post- fair value period. This clearly shows a decline in investors focus on financial assets recognized under the principle of fair value which increases more complexity in recognition of these financial assets and which derivatives have the famous. Indeed, the coefficient of determination fell $93.94 \%$ (from $52.32 \%$ (prefair value (M1.3)) to $3.17 \%$ (post- fair value (M2.3))). Thus, H1.3 hypothesis is disproved. This finding is at odds with studies of Barth (1994), Ahmed and Takeda (1995), Barth and al. (1996), Venkatachalam (1996), Shrand (1997) and Park and al. (1999) that reveal a better relevance to the principle of fair value compared to historical cost for investment securities, gains and realized and unrealized losses, derivatives and securities available for sale . For goodwill, we find that their relevance to disclose information on stock return has improved significantly by applying the principle of fair value: the coefficient of determination R2 increased from $16.56 \%$ (pre- fair value (M1. 4)) to $28.77 \%$ (post- fair value (M2.4)). Therefore, the fair value seems more relevant than historical cost to disclose goodwill that carries information to investors on the stock return. Thus the hypothesis H1.4 is confirmed. Our result is consistent with the study of Barth and Clinch (1998). This indicates that the new regulations issued by IFRS in accounting for goodwill (fair value principle) attract more the investor attention compared to the General Accounting Plan (historical cost). In summary, the analysis of simple regressions allows us to conclude that the fair value is used only to improve the relevance of earnings per share and goodwill. Thus, the first hypothesis $\mathrm{H} 1$ is partially confirmed.

\subsubsection{Multivariate analysis}

In Table 3 which is summarized from (Appendix.2), the regression coefficients indicate that the earnings per share became significant after the application of the principle of fair value. Equity is always significant before and after the application of the fair value at conventional levels of $1 \%$ and $5 \%$ respectively. This result is in agreement with the study of Chen and Dodd (1997) which show that equity can still serve as a signal for investors. Financial assets are significant at the $5 \%$ level in the pre-fair value model but become insignificant in the post- fair value model. Goodwill is also significant for the two sub -periods (pre- and post- fair value) at the conventional threshold of $1 \%$. This result is consistent with studies of Peasnell and Mather (1991), Seethamraju (2003) and Cazavan (2003) which stipulate an existence of a positive and significant correlation between goodwill and stock return. Taken together, the historical cost show clearly that with the application of the principle of fair value only financial assets become insignificant. This, as we have already mentioned in the section dedicated to the bivariate analysis indicates that with the application of the fair value investors show a dazzling back to focus on the financial assets given the complexity and even the darkness in the provisions of their recognition. The results in Table 3 show also that the intensity of the association between stock returns and variables that are significant for the two sub -periods, namely equity and goodwill appears more important in applying the principle of fair value ( 0.328 to 0.963 for equity and 0.922 to 1.097 for goodwill). Similarly, it appears that earnings per share is still the best to attract investors to the information content even after the application of fair value with a coefficient of 2.902, which is higher than those of goodwill and equity that are 1.097 and 0.963 respectively. Thus, based on the coefficient of determination R2 as a measure of relevance of the association between the listed variables and stock returns, it turns out that the model based on historical cost has an explanatory power $(62.82 \%)$ which is higher than that based on the fair value $(58.63 \%)$. So the principle of fair value cannot improve the explanatory power of the model and our second hypothesis is disproved. This finding contradicts the results found by Khuranna and Kim (2003) who approved that the model examining variables submitted with the principle of fair value is more explanatory than the one based on historical cost.

Table 3: Results of Multiple Regressions for the Periods Pre- and PostFair Value Fair Value

\begin{tabular}{llllllll}
\hline Period & $\begin{array}{l}\text { Econometric } \\
\text { models }\end{array}$ & $\mathrm{B}_{1}$ & $\mathrm{~B}_{2}$ & $\mathrm{~B}_{3}$ & $\mathrm{~B}_{4}$ & $\mathrm{R}_{2}$ & $\mathrm{~F}$ \\
\hline $\begin{array}{l}\text { Pre- } \\
\text { fair }\end{array}$ & $\mathrm{M} 1$ & $\begin{array}{l}0,208 \\
(0,82)\end{array}$ & $\begin{array}{l}0,328 \\
(3,67)^{* *}\end{array}$ & $\begin{array}{l}-1,855 \\
(2,59)^{*}\end{array}$ & $\begin{array}{l}0,922 \\
(3,15)^{* *}\end{array}$ & $62,82 \%$ & $\begin{array}{l}16,90 \\
(0,00)^{*}\end{array}$ \\
$\begin{array}{l}\text { value } \\
\begin{array}{l}\text { Post- } \\
\text { fair } \\
\text { value }\end{array}\end{array}$ & M2 & $\begin{array}{l}2,902 \\
(4,17)^{* *}\end{array}$ & $\begin{array}{l}0,963 \\
(2,04)^{*}\end{array}$ & $\begin{array}{l}0,093 \\
(0,09)\end{array}$ & $\begin{array}{l}1,097 \\
(2,79)^{* *}\end{array}$ & $58,63 \%$ & $\begin{array}{l}14,17 \\
(0,00)^{*}\end{array}$ \\
\hline
\end{tabular}

** And *: significant at $1 \%$ and $5 \%$ respectively

\section{Conclusion}

The admission of the principle of fair value in the consolidated European accounts derives from the desire to design a financial communications for companies based on economic data rather than historical data. Accounting will now more concern appearance than substance: the balance sheet may be subject to a revaluation to reduce the "gap" between the book value and the market value. We wondered, in this paper, about the ability of an accounting model based on fair value to improve or not the informational extended of accounting data for investors. Thus, our objective was to study in the French context the impact of the application of fair value on creating shareholder value by comparing the value relevance of the informational content of accounting indicators for groups of companies in the industrial sector which are included in the CAC All -Tradable index between the pre- fair value period (2001-2003) and the post- fair value period (2005-2007). The approach has led us, first, to empirically test four models. These models are basic and highlight on one side only the relationship between earnings per share, equity, financial assets and goodwill and the stock return on the other side during pre- fair value and post- fair value periods. In a second step, we propose an extension of the first models by combination all variables in a single model. The first is for the pre- fair value period and the other is for the post fair value period. The comparison's analysis of coefficients of determination as a measure of relevance between the market variable and accounting variables in the model between the two subperiods chosen led to the following conclusions: The first part based on bivariate analysis confirms that earnings per share and goodwill submitted under the principle of fair value are more carriers of information on the value created by the firm than when they were submitted under the principle of historical cost. However, this same analysis does not produce the same results for the other two variables which are equity and financial assets of the fair value which saw, with the application of the fair value, an aversion from investors. The second step based on multivariate analysis led us to reject the second hypothesis of our research. Indeed, the recognition of accounting indicators with the principle of fair value does not improve the explanatory power of the model, which was submitted under the historical cost.

In short, through this study, we found, first, that the traditional character variables (EPS, EQ) still retain their rank as key indicators determining stock return whatever the accounting principle 
relating to it and we have noted, secondly, that there is a marked improvement in informational content of the variables if and only they were submitted in understandable rules instead of complex fair value. This is clearly in the example of the financial assets that, with the application of the principle of fair value, suffer a setback in their perceptions on the part of investors. However, the findings of this research are tainted with some limitations that open new horizons. First, the period in which we analyzed the data finds as little compared to studies on panel data. Zarowin and Lev (1999) determine that the relevance of accounting data is more dazzling if the period of study exceeds twenty. Another limitation concerns the fact that we chose variables estimated to be the most affected by the principle of fair value may be insufficient to measure the relevance in terms of value creation. In this respect, our analytical framework and empirical confirmation could be enriched by taking into other accounting indicators and by a broadening to other European countries will admit possibly to make more robust results.

\section{References}

[1] Ahmed, A-S. and Takeda C. (1995), "Stock market valuation of gains and losses on commercial banks' investment securities: an empirical analysis », Journal of Accounting and Economics, vol. 20, pp. 207-225. http://dx.doi.org/10.1016/0165-4101(95)00396-Z.

[2] Ball, R. and Brown P. (1968), "An empirical evaluation of accounting income numbers", Journal of Accounting Research, autumn, pp $159-177$.

[3] Barth, M-.E. And Clinch G. (1998), "Revalued financial, tangible, and intangible assets: associations with share prices and nonmarket-based value estimates", Journal of Accounting Research, vol. 36, pp. 199-33. http://dx.doi.org/10.2307/2491314.

[4] Barth, M- E., Landsman W. R. and Lang M. H. (2008), "International Accounting Standards and Accounting Quality", Journal of Accounting Research, vol. 46, n³, pp.467-498. http://dx.doi.org/10.1111/j.1475-679X.2008.00287.x.

[5] Barth, M., Beaver W. and Landsman W. (2001)," the value relevance literature for financial accounting standard setting: another view", Journal of Accounting and Economics, vol.31, pp. 77-104 http://dx.doi.org/10.1016/S0165-4101(01)00019-2.

[6] Barth, M., Landsman W. and Wahlen J.M.( 1995), "Fair value accounting: effects on banks' earnings volatility, regulatory capital, and value of contractual cash flows",Journal of Banking and Finance, vol.19, $\mathrm{n}^{\circ} 3$, pp. 577-605. http://dx.doi.org/10.1016/03784266(94)00141-O

[7] Barth, M-E. (1994), "Relative measurement errors among alternative pension asset and liability measures", The Accounting Review, vol. 66, issue 3, pp. 433-463.

[8] Barth, M-E. (2004), "Fair Values and Financial Statement Volatility", in the Market Discipline across Countries and Industries", Edited by Claudio Borio, William Curt Hunter, George G. Kaufman and Kostas Tsatsaronis, Cambridge, MIT Press.

[9] Barth, M-E. , Beaver W-H. and Landsman W R. (1996), "ValueRelevance of banks' fair Value Disclosures under SFAS No.107", The Accounting review, vol. 71,n॰4, pp. 513-537.

[10] Bartov, E., Goldberg S. and Kim M. (2005), "Comparative value relevance among German, US, and International Accounting Standards: A German stock market perspective", Journal of Accounting, Auditing \& Finance, vol20, pp.95-119.

[11] Beaver, W. (1998), "Financial reporting: an accounting revolution", prentice Hall, Upper saddle river, Contemporary topics in accounting series, 3ème éd.

[12] Beaver, W-H. (1968), "The information content of annual earnings announcements", Journal of Accounting and Research, Vol. 6, n³, supplement, pp 67 - 92. http://dx.doi.org/10.2307/2490070.

[13] Carroll, T-J., Linsmeier T-J. and Petroni K.R. (2003), ’The reliability of fair value versus historical cost information: evidence from closed-end mutual funds ", Journal of Accounting, Auditing and Finance, vol. 14, winter, pp. 1-23.

[14] CASTA, J-F. (2003), « La comptabilité en juste valeur permet-elle une meilleure représentation de l'entreprise ?, Juste valeur et évaluation des actifs », Revue d'Economie Financière, Paris, nº 71 , pp. 17-31.

[15] Casta, J-F. and Colasse B. (2001), «Juste Valeur : enjeux techniques et politiques », Economica.
[16] Cazavan-Jeny, A. (2003), « Le ratio market-to-book et la reconnaissance des immatériels: une étude du marché français », CD Rom du 24 ème congrès de l'AFC, mai.

[17] Chen, S. and Dodd J-L. (1997), "Economic Value Added (EVA): An Empirical Examination of a New Corporate Performance Measure". Journal of Managerial Issues (fall), pp. 318-333.

[18] Christensen, H., LEE E. and WALKER M. (2009), "Do IFRS reconciliations convey information? The effect of debt contracting", Journal of Accounting Research, vol.47, pp.1167-1199. http://dx.doi.org/10.1111/j.1475-679X.2009.00345.x.

[19] Collins, D. and Kothari S. (1989), "A theoretical and empirical analysis of the determination of earning response coefficients ", Journal of Accounting and Economics, vol. 11, pp. 143-181. http://dx.doi.org/10.1016/0165-4101(89)90004-9.

[20] Dechow, P-M. (1994), "Accounting earnings and cash-flows as measures of firm performance: the role of accounting accruals ", Journal of Accounting and Economics, vol.18, pp. 3-42. http://dx.doi.org/10.1016/0165-4101(94)90016-7.

[21] Desmoutier, H. (1994), « La contribution de la théorie financière à la stratégie et vice versa », Cahier de recherche de l'ESUG, Toulouse.

[22] Dumontier, P. and Raffournier B. (1998), "Why firms comply voluntarily with IAS: An empirical analysis with Swiss data", Journal of International Financial Management and Accounting, vol. 9, no 3, pp. 216-245. http://dx.doi.org/10.1111/1467-646X.00038.

[23] Easton, P. and Harris T. (1991), "Earnings as an explanatory variable for returns ", Journal of Accounting Research, vol. 29, n 1, 99. 19-35.

[24] Eccher, E A., Ramesh K. and Thiagarajan H. (1996), "Fair value disclosures by bank holding compagnies", Journal of Accounting and Economics, vol. 22, pp.79-117. http://dx.doi.org/10.1016/S0165-4101(96)00438-7.

[25] Ewert, R. and Wagenhofer A. (2005), "Economic effects of tightening accounting standards to restrict earnings management", The Ac$\begin{array}{lllll}\text { counting Review, } & 80, & 1101 & - & 1124\end{array}$ http://dx.doi.org/10.2308/accr.2005.80.4.1101.

[26] Gorchakov, I. (2009), "paper profits: the role of fair value accounting in dividend policy", Amsterdam business school, September.

[27] Hamdi, B. and Elabidi H. (2009), «l'information comptable en juste valeur : quelle utilité pour les investisseurs ?, La place de la dimension européenne dans la Comptabilité Contrôle Audit, Strasbourg.

[28] Harris, T., Lang M. and Möller H. (1994), "The value relevance of German accounting measures: an empirical analysis", Journal of Accounting Research, Vol. 32, N², autumn, pp 187 - 209.

[29] Hassan, MS., Percy M. and Stewart J. (2006), "the value relevance of fair value disclosures in australian firms in the extractive industries", Asian academy of management journal of accounting and finance (AAMJAF), Vol. 2, No. 1, pp.41-61.

[30] Jacquet, D. (1997), «Rentabilité et valeur : EVA et MVA », Analyse Financière, ${ }^{\circ} 112$, septembre, pp.52-62.

[31] Jeanjean, T. and Stolowy H. (2008), "Do accounting standards matter? An exploratory analysis of earnings management before and after IFRS adoption", Journal of Accounting and Public Policy, vol.27, $n^{\circ} \quad 6, \quad$ pp.480-494 http://dx.doi.org/10.1016/j.jaccpubpol.2008.09.008.

[32] Juettner-Nauroth, B. (2003), "Problems associated with the ValueRelevance of Financial Derivatives according to IAS 39", SSE/EFI Working Paper Series in Business Administration, $\mathrm{n}^{\circ} 2003$-2.

[33] Khuarana, I-K. and Kim M-S. (2003), "Relative value relevance of historical cost $v s$. fair value: evidence from bank holding companies ", Journal of Accounting and Public Policy, vol. 22, $\mathrm{n}^{\circ} 1$, pp. 1942. http://dx.doi.org/10.1016/S0278-4254(02)00084-4.

[34] Koch, S. and Trémolières R. (1995), « Evaluation économique et stratégique de l'entreprise : évolution et nouvelles tendances », Analyse financière, septembre, ${ }^{\circ} 104$, pp.75-84.

[35] Kothari, S. (1992), "Price-earnings regressions in the presence of prices leading earnings: earnings level versus change specification and alternative deflators ", Journal of Accounting and Economics, vol. 15 , pp. 173-202. http://dx.doi.org/10.1016/01654101(92)90017-V.

[36] Landsman, W. and Maydew E. (1999), "Beaver (1968) Revisited: Has the information content of annual earnings announcements declined in the past three decades? », Working paper, University of North Carolina.

[37] Lev, B. and Zarowin P. (1999), "The boundaries of financial reporting and how to extend them", Journal of Accounting Research, autumn, pp. 353-385. http://dx.doi.org/10.2307/2491413. 
[38] Martinez,I. (2004), « le contenu informatif des chiffres comptables : vers de nouvelles amélioration méthodologiques »Comptabilité, Contrôle, Audit. Tome 10, vol.2, pp. 9-30.

[39] Mather, P-R. and Peasnell K-V. (1991), "An examination of the economic circumstances surrounding decisions to capitalize brands “, British Journal of Management, vol. 2, pp. 151164. http://dx.doi.org/10.1111/j.1467-8551.1991.tb00023.x.

[40] Nelson, K. (1996), "Fair value accounting for commercial banks: an empirical analysis of SFAS $\mathrm{n}^{\circ} 107$ ", The Accounting Review, vol. $71, \mathrm{n}^{\circ} 2$, avril, pp. 161-182.

[41] Parienté, S. (1997), « La création de valeur par l'entreprise », Analyse Financière, ${ }^{\circ} 112$, septembre, pp.63-72.

[42] Park, M., Park T. and Ro B. (1999), "Fair value disclosures for investment securities and bank equities: evidence from SFAS $\mathrm{N}^{\circ}$ 115", Journal of Accounting Auditing and Finance, vol. 14, n ${ }^{\circ} 3$, pp. $347-370$.

[43] Ramond, O., Batsch L. and Casta JF. (2007), « Résultat et performance financière en normes IFRS : Quel est le contenu informatif du comprehensive income ? », Research paper $n^{\circ}$ 2007-04, Université Paris Dauphine.

[44] Saadi, T. (2010), «Création de valeur : l'impact des normes IFRS sur le contenu informationnel du résultat net : le cas de la France », CESAG.

[45] Saadi, T. (2010), «contenus informationnels du résultat net et des capitaux propres : quelle pertinence après l'introduction des normes IFRS : le cas de la France », CESAG (centre d'études des sciences appliquées à la gestion), école de management Strasbourg, université de Strasbourg.

[46] Schrand, C. (1997), "The association between stock-price interest rate sensitivity and disclosures about derivative instruments", The Accounting Review, vol. 72, $\mathrm{n}^{\circ} 1$, janvier, pp. 87-109.

[47] Venkatachalam, (1996), "Value relevance of banks' derivatives disclosures", Journal of Accounting and Economics, pp.327-355. http://dx.doi.org/10.1016/S0165-4101(96)00433-8.

\section{Appendix 1}

Pearson correlation coefficients between the independent variables

Pearson correlation coefficients between the independent variables in the model (M1)

\begin{tabular}{lllll}
\hline & EPS & EQ & FINAS & GW \\
\hline EPS & 1 & 0,6857 & 0,7557 & 0,4941 \\
EQ & $0,6857 * *$ & 1 & 0,6200 & 0,5775 \\
FINAS & $0,7557 * *$ & $0,6200 * *$ & 1 & 0,6967 \\
GW & $0,4941^{* *}$ & $0,5775^{* *}$ & $0,6967 * *$ & 1 \\
\hline
\end{tabular}

Pearson correlation coefficients between the independent variables in the model (M2)

\begin{tabular}{lllll}
\hline & EPS & EQ & FINAS & GW \\
\hline EPS & 1 & $-0,0204$ & 0,2905 & 0,2538 \\
EQ & $-0,0204^{*}$ & 1 & 0,0623 & 0,2422 \\
FINAS & $0,2905^{*}$ & $0,0623^{*}$ & 1 & 0,2842 \\
GW & $0,2538^{*}$ & $0,2422^{*}$ & $0,2842^{*}$ & 1 \\
\hline
\end{tabular}

** And *: significant at $1 \%, 5 \%$ respectively

\section{Appendix 2}

The results of multiple regressions results of the model estimation $\mathrm{m} 1$

\begin{tabular}{lll}
\hline Variables & Coefficient & Significance \\
\hline EPS & 0,208 & 0,82 \\
EQ & 0,328 & $3,67^{* *}$ \\
FINAS & $-1,855$ & $2,59^{*}$ \\
& 0,922 & $3,15^{* *}$ \\
\hline GW & \\
& Results of the model estimation M2 \\
\hline Variables & Coefficient & Significance \\
\hline EPS & 2,902 & $4,17^{* *}$ \\
EQ & 0,963 & $2,04^{*}$ \\
FINAS & 0,093 & 0,09 \\
GW & 1,097 & $2,79^{* *}$ \\
\hline
\end{tabular}

** And *: significant at $1 \%, 5 \%$ respectively 